\title{
AMPUTATION HISTORY AND REHABILITATION OF BLACK MEN LIVING IN THE GREATER DURBAN AREA WHO HAVE HAD TRAUMATIC AMPUTATIONS OF THE LOWER LIMB.
}

\author{
BA Kubheka and LR Uys
}

\section{OPSOMMING}

Hierdie artikel beskryf " $n$ opname onder 25 swart mans met "n amputasie van "n onderste ledematat met die doel om hut sorg rondom die amputasie en hal rehabilitasie daarna te beskryf. Die steekproef het gewisel van 24 en 50 jaar ouderdom en die meeste was van die platteland.

Wat die sarg rondom die amputasie betref, was die gebrek aan psigiese voorbereiding, en die gebrek aan rehabiliasie onderrig na die tyd, die uilstaande bevinding. Dif meeste respondente moes die meeste dinge maar self utrind.

Hierdie gebrek aan inligting en onderrig het fisiese rehabilitasie bemoeilik, met amputasie-sere en gebrekkige gebruik van prosteses as die belangrikste probleme. Werksrehabilitasie was omtrent totaal ofwesig. In teenstelling met die 22 respondente wat voor die amputasie gewerk het, was net vier daarna werksaam. Die meeste moes steeds hul families alleen onderhou, 16 van hulle met 'n Ongeskiktsheidstoelaag. Bostaande probleme het ook meegewerk tot sosiale isolasie, depressie, eensaamhieden ander psigososiale probleme.

\section{ABSTRACT}

A survey was undertaken amongst twenty five black men living in the greater Durban area who had had amputations of the lower limbs. The type of amputation care and the rehabilitation programme they underwent post-operatively is described. The sample included men from 24 to 50 years of age, of whom the majority were from rural areas.

The amputation care intra and post-operatively was marked by the lack of emotional preparation pre-operaively, and lack of rehobilitation information and teaching afterwards. Most respondens had to find information for themselves.

This lack of information and teaching seemed to impede physical rehabilitation, with stump sores and limited use of prostheses being the main problems. Vocational rehabilitation was almost totally absent. In contrast to the twenty two respondents who worked before their amputations, only four worked ofterwards. The majority had to support their families alone; sixteen of them were totally reliant on a Disability Grant. These problems lead to social isolation, depression, loneliness and ather psycha-social probtems.

\section{INTRODUCTION}

Amputation of the lower limbs due to trauma mostly is seen in young males between the ages $18-50$ years. The increased use of high speed transportation and an upsurge in industrial activities are associated with the high incidence of trauma, especially in young male patients. This age group is a critical group for rehabilitation because they are expected to be productive in their families, community and society.

However in the writer's experience poor rehabilitation seems to be common. Some amputees come into the outpatient clinics with broken prostheses and old broken crutches, not knowing anything about a disability grant or having any money to attend the hospital or the clinic to purchase these appliances.
Poverty is a severe problem. Besides those coming to the hospital or the clinic, some amputees can be seen around the street corners begging for money and some homeless patients are to be found all over the city living on the streets.

The current provision of rehabilitation services can be illustrated by describing the process at the amputation clinic of one large urban hospital in Durban. It caters for all patients from Natal and some from $\mathrm{K}$ wazulu. On each clinic day it attends to about 5-10 amputees. The policy of the hospital states that all the amputees who were initially treated in the hospital must have their follow-up at the clinic provided by the hospital. The reason for this is that peripheral hospitals in Natal have no specialist team available to cater for the needs of amputees. To allow for proper supervision and correct fitting of the prostheses, the amputation clinic is centralized around a team consisting of the orthopaedic surgeon, a prosthetist from the orthopaedic workshop, a physiotherapist and a nurse.

Very little research has been done in the KwaZulu Natal on the rehabilitation of young people with amputations. Most amputations are done on elderly patients with peripheral vascular disease (Wilson, 1983). It therefore was important to investigate the experience of young amputees in this area.

\section{OBJECTIVES OF THE STUDY}

1. To describe the care that patients who have undergone traumatic amputation received in the health service.

2. To describe the physical, psycho-social and vocational rehabilitation of these patients.

3. To identify health care or nursing care needs of these patients.

\section{DEFINITION OF TERMS}

A mputation is defined as loss of part or all of a limb (Footner, 1987). In this study only lower limb amputations are included. 
Amputation History This includes admission of the patient into the hospital, pre-operative, post-operative care, discharge planning and community reintegration.

Rehabilitation is defined as restoration of the individual to the fullest physical, mental, social, vocational and economic capacity of which he is capable (Stryker, 1977).

\section{LITERATURE SURVEY}

\section{Physical Rehabilitation}

According to Broadhurst (1989), stump care must be carried out daily by the nurses during a patient's hospitalization, and the patient must be taught how to do this himself. Stump care encourages wound healing and it is important in preparing the stump for fitting of the prosthesis. This includes massage of the stump, positioning, bandaging and exercise. Powell (1982) stated that positioning of the patient following surgery, especially positioning of the stump is very important to prevent formation of contractures.

According to Smith (1987), bandaging the stump for proper shaping is also important because if the stump is not shaped properly, prosthetic fitting will be difficult; he stresses that the patient should be taught how to do this for himself.

Massage of the stump has physiological and psychological effects. Physiologically it stimulates circulation and relieves pain and psychologically it encourages handling of the stump so that the amputee gets a realistic recognition of the amputation which reduces phantom sensations. This must be done after stump cleansing and before applying the bandage (Broadhurst 1989).

Exercises of the stump are also essential in order to prevent complications such as contractures. Included with the stump exercises are those exercises related to deep breathing and coughing to prevent pulmonary embolism, and exercises of the whole body especially the upper liunbs which will be used when ambulating the patient on crutches (Footner, 1987).

Ambulation or mobility must be achieved about 4-6 days post-operatively to prevent bedrest complications and the amputee is encouraged to learn free standing balance on one leg to prepare him for ambulation and walking independently. (Farrell, 1982)

Martin, Holt and Hicks (1981) point out that a patient must be measured and fitted with a pylon very soon after amputation to enable mobilisation early after operation; orientation must be done by explaining to the patient the reason for measuring a pylon, as this is often a cosmetic shock.

When it is established that he is proficient in using a pylon a permanent prosthesis is fitted. The speed with which the patient adjusts to the prosthesis depends partly on the age, and general condition and condition of the stump (Farrell, 1982).

Powell (1982) describes how care of the prosthesis is done by the prosthetist who will teach the amputee how to put a prosthesis on. how to remove it, how to care for it and use it at home to keep it in good condition and prevent injuries.

\section{Psycho-social rehabilitation}

Adjusting to the change in body image and the limitation of mobility with all the social, economic and psychological ramifications involved is a momentous task for any person and requires a lot of support from all involved in his rehabilitation (Farrell, 1982). A rehabilitated amputee who has shown high motivation during rehabilitation and who might be interested in helping others build their independence may be used to visit the new amputee in order to help him cope with his disability (Footner, 1987).

Other authors such as Martin. Holt and Hicks, (1981) suggest the usefulness of a visit to a limb fitting centre where the patient has the opportunity to meet other amputees. This would encourage an awareness that the loss of a limb need not necessarily interfere with a flexible lifestyle and that the resumption of work would be beneficial.

Most amputees who return to their homes require some adaptation of their dwellings, which should be done before discharge (Weaver and Marshall, 1973). Liaison with the social services department is necessary to ensure these alterations are undertaken if required (Footner, 1987). Thompson and Haran (1985) found that the key helpers of amputees were mostly women, with $82 \%$ being wives of the amputees with the majority living in the same household as the patients they were helping. Having someone to talk to is very important in the social rehabilitation of the amputee. Lack of confiding relationships with a partner may be a contributing factor in the aetiology of depression (Park, 1991). Chilvers and Browse (1971) agreed with these findings and reported that amputees often did not have known sources of assistance for their practical problems, and that relatives were the most common helpers.

\section{Vocational Rehabilitation}

Powell (1982) stressed that there is need for investigation of occupational possibilities to promote return to previous employment or to establish the need for returning to a new job. Mets and Wilson (1989) contend that the main aim of their rehabilitation centre in Cape Town is to prepare physically disabled persons for suitable employment in the open market, by training and educating them in the workplace which resembles the realistic work situation as much as possible. Gillies (1991) agreed with the above view point in that corroct placement of the employee with a disability is of paramount importance, ensuring he is able to be effective in his job and remains with the company. du Toit (1989) insists that an income generating disabled person would be in a stronger position to help himself in all areas of his life.

\section{METHODOLOGY}

This was a descriptive survey using semi-structured interviews with selected young black men living in KwaZulu Natal who had sustained lower limb amputation as a result of trauma. The purposive sample consisted of 25 young black men between the ages of 18-50 years who had sustained lower limb amputation due to trauma. There is no South African or provincial central disability register and it was very difficult to find this category of patient. The men almost all were located in the greater Durban area.

Attempts were made to obtain a sample by checking admission and discharge books of orthopaedic wards and male surgical wards in a large urban hospital. Only two respondents were found through this procedure because a number of patients could not be traced at the given addresses.

Attempts of identifying amputees through the Workmen's Rehabilitation Centre in Durban failed because many patients were no longer working. Only one respondent was interviewed at work. Patients coming into the orthopaedic outpatient department and amputation clinic for follow up visit in the same urban hospital were interviewed. This approach was successful and 22 respondents were identified in this manner.

\section{Data Collection}

The interview schedule was divided into five categories: demographic information, amputation history, psycho-social rehabilitation, physical rehabilitation and vocational rehabilitation. All these categories are based on the conceptual framework of rehabilitation nursing as described by Dittmer (1989).

While most of the item responses in the questionnaire were based on the information given by respondents, six were based on observation and inspection in order to confirm the reality of the problems encountered by the amputees.

A pilot study was conducted on five hospitalised amputees and five discharged amputees showing that the instrument delivered the required information.

Content validity of the instrument can be argued because it was based on a conceptual framework of rehabilitation nursing focusing on the amputation history and rehabilitation of amputees as discussed in the literature survey.

Face validity of this instrument seems to be acceptable. All the questions asked are related 
to the amputation history and rehabilitation of young black men and the respondents found them acceptable.

Reliability of the instrument may be influenced by the ability of patients to remember and the honesty with which they answer questions; some amputations were carried out many years previous to interview.

Data were obtained through semi-structured interviews allowing respondents to express their views freely without restraint. Interviews consisted of closed and open ended questions and were carried out in Zulu to facilitate good communication. Each interview took about 30-45 minutes to complete depending on the patient's ability to remember his experiences. The researcher personally carried out all interviews.

\section{FINDINGS}

The ages and marital status of the men are given in Tables 1 \& 2 . Twelve men had above-knee and 13 had below-knee amputations. Each group included one bilateral amputee.

\begin{tabular}{|c|c|c|}
\hline \multicolumn{3}{|c|}{$\begin{array}{c}\text { TABLE } 1 \text { AGE DISTRIBUTION OF } \\
\text { THE AMPUTEES }\end{array}$} \\
\hline AGE & $\begin{array}{l}\text { NO. OF } \\
\text { RESPONDENTS }\end{array}$ & $\%$ \\
\hline $24-30$ yrs & 11 & 44 \\
\hline $31-40$ yrs & 10 & 40 \\
\hline $41 \cdot 50$ yrs & 4 & 16 \\
\hline TOTAL & 25 & $100 \%$ \\
\hline
\end{tabular}

\begin{tabular}{|c|c|c|}
\hline \multicolumn{3}{|c|}{ TABLE 2 MARITAL STATUS } \\
\hline $\begin{array}{l}\text { MARITAL } \\
\text { STATUS }\end{array}$ & $\begin{array}{c}\text { NO. OF } \\
\text { RESPONDENTS }\end{array}$ & $\%$ \\
\hline Single & 16 & 64 \\
\hline Married & 9 & 36 \\
\hline TOTAL & 25 & 100 \\
\hline
\end{tabular}

\section{AMPUTATION HISTORY}

Duration of time as an amputee is given in Tables 3 and 4.

\section{TABLE 3 DURATION OF TIME AS AMPUTEE}

NUMBER OF
YEARS
1
$2 \cdot 5$
$6-14$
$15-35$

NO. OF
RESPONDENTS
2
12
7
4

TABLE 4 DURATION OF STAY BEFORE OPERATION

\begin{tabular}{|cc|} 
DURATION OF STAY & NO. OF \\
BEFORE AMPUTATION & RESPONDENTS \\
Amputation same day & 15 \\
Within 4 days & 7 \\
Within 4 weeks & 2 \\
Later than 4 woeks & 1 \\
TOTAL & 25 \\
\hline
\end{tabular}

After traumatic amputation the patient is sent to theatre for first amputation. If the wound is clean, wound closure is performed. In this study only four of the patients were sent to theatre for one revision procedure. The rest were sent to theatre between two to six times depending on the condition of the stump.

All patients stated that they saw only the doctor before the amputation, and no other team members. No difference was found between those patients who were operated on the same day and those who had their operations performed later. Although there is often no time to prepare the patients with traumatic amputation, those who were in the hospital for longer were supposed to be seen by other members of the team, especially the physio- therapist. These findings reveal an unco-ordinated approach to rehabilitation of the amputees

Some respondents stated that no one explained to them about surgery. They woke up when the limb was already amputated. Three of the respondents were deeply unconscious when they were sent to theatre for amputation. The other patients who were operated on from four days to two and half months later received explanations from the doctors and nurses. No respondent mentioned that explanation was done by a nurse alone. It was always a doctor or a doctor and the nurse. These findings seem to point to lack of independent teaching by the nurse in the preparation of patients for surgery.

Seven family members received no explanation of the operation. Only eighteen families were given information about the operation and eight of these were informed by amputees themselves after amputation. These findings showed a great lack of family involvement and preparation.

All the respondents stated that family members experienced great shock after receiving the news that one of their family members had an amputation. This revealed a great need for psychological support in the preparation of the family.

\section{PHYSICAL REHABLIITATION}

There was a general lack of education of the patient about stump care and bandaging. Half of the respondents mentioned that they were not taught. but learned from experience by looking at the nurses and physiotherapists doing it on other patients.

Most of the patients were not taught about problems that can occur on the stump; the most common problems bringing patients to the clinic were stump problems. The teaching that was done seemed to have been haphazard.

Eleven respondents stated that they were not oriented about the limb fitting centre. Twelve stated that it was done when they were fitted with their prosthesis. This revealed a general lack of psychological preparation of patients about prostheses which may have affected their motivation and participation in their rehabilitation programme.

The twelve respondents who were using prostheses at the time of the interview were educated about the use and care of the prosthesis by the prosthetist at a limb fitting centre.

Four respondents were shown how to transfer by the physiotherapists. Most of the amputees stated that they learned these techniques themselves.

Three of the twelve amputees who had a prosthesis were not wearing them at the clinic. Those not having them on had different reasons. Eight respondents stated that they had no money to purchase a prosthesis. Five respondents were still in the process of purchasing one from the orthopaedic workshop.

With one exception, all amputees who came into the clinic wearing a prosthesis stated that their prosthesis fitted them well. The exception stated that sores developed after wearing it while travelling a long distance.

Appliances used for mobility are shown in Table 5.

\section{TABLE 5 APPLIANCES USED FOP MOBILITY}

\begin{tabular}{lc} 
APPLIANCES USED & NO. OF \\
& RESPONDENTS \\
Crutches & 9 \\
Prosthesis only & 7 \\
Prosthesis with crutches & 2 \\
Walking Stick with prosthesis & 3 \\
Wheelchair & 2 \\
A crutch and a walking stick & 1 \\
Crutches and boot & 1 \\
TOTAL & 25 \\
\hline
\end{tabular}

\section{Psycho-social Rehabilitation}

All the patients said that their home environment has not adapted for them. Before discharge, no one was sent out to the patient's home to check the surroundings, or to advise about possible alterations that might be needed to ensure the patient's ability to move around in their own homes after discharge.

Most of the patients stated that they were doing nothing at home after discharge. This exacerbated their loneliness. Very few were involved in doing something such as temporary jobs or occupying themselves with hobbies.

Most of the amputees were found to be staying with their families, especially wives and mothers but 3 quite independent men were staying alone. Eight stayed with their wife and 6 with their mother. Twenty-three men were found to be independent in their activities of 
daily living, with helpers only washing their clothing, cooking food and cleaning the house. The two men who had sustained bilateral amputation needed substantial help. Most of the amputees were unable to pay for these helpers because they had no money, and in some cases were helped by their relatives. Only two amputees were able to apply for helpers because they were working.

Almost all of them knew nobody else with an amputated leg. Only two respondents stated they had seen somebody, and these people were not inspirations since they were living on disability grants and not working.

Only sixteen out of twenty five amputees were anticipating financial compensation after the accident which caused the disability. Ten of these were still waiting for their claims from third party insurance. Only two patients had already received their third party insurance claims. The rest of the patients had not received anything. Six amputees were waiting for compensation from Workmen's Compensation Insurance. Some of the ampulees were not expecting anything since they were injured during the riots or train accidents.

Fourteen of the amputees were getting disability grants, but combining it with other activities because the disability grant was not enough for them to support their families. Eleven amputees were not getting any income and were starving. Table 6 shows sources of income of respondents.

\section{TABLE 6 SOURCE OF INCOME OF 25 AMPUTEES}

$\begin{array}{lc}\text { SOURCE OF INCOME } & \begin{array}{c}\text { NO. OF } \\ \text { RESPONDENTS }\end{array} \\ \text { Disability Grant } & 14 \\ \text { No income } & 11 \\ \text { Disability grant and selling } & 3 \\ \text { Repaining shoes/radios } & 2 \\ \text { Tuck Shop } & 1 \\ \text { Gardening } & 2 \\ \text { Making bags } & 1\end{array}$

Most of the amputoes were responsible for supporting their families. Twelve were supporting their families alone. Three were supporting their families helped by their mothers, two helped by their fathers and one helped by the wife. Three amputees stated that there was nobody supporting the family: the family was starving. Two of the respondents were living on the pensions of mothers and grandmothers. One amputee stated that he did not know anything about a disability grant.

Twenty-one amputees were accepted back home after amputation. Four of the amputees were rejected by their families. One was rejected by the father, one by the mother, and one by the girlfriend. The fourth amputee was the only child when he lost his limb and after the death of the parents he was staying alone.
VOCATIONAL REHABILITATION

Eighty percent of the amputees were working before the injury in different capacities. Their employment histories are shown in Table 7.

\begin{tabular}{|lcc|}
\hline \multicolumn{3}{|c|}{ TABLE 7 EMPLOYMENT BEFORE } \\
AND AFTER INJURY \\
OCcUPATION & BEFORE & AFIER \\
Not employed & 5 & 2 \\
Labourers & 4 & 1 \\
Security guards & 3 & - \\
Domestic servant & 1 & - \\
Drivers & 3 & - \\
Cashier & 1 & - \\
Car welding & 1 & - \\
Machine fitter and & 2 & - \\
operator & & \\
Cement mixer & 1 & - \\
Meat delivery & 1 & - \\
Butcher & 1 & - \\
Laboratory technician & 1 & 1 \\
Conductor & 1 & - \\
TOTAL & 25 & 4 \\
\hline
\end{tabular}

Different reasons were given by amputees for not working after injury. Three of them were still looking for work, but were told by employers that there is no suitable work for them. Some stated that they do not want to work because they are getting a disability grant, one of the ampulees said he did not think that he would be able to cope with the strain of his previous job. One was told by his employer that his standard of education was too low (standard three) and that he was looking for someone with at least a standard ten. One of the amputees was employed in one of the factories, but on medical examination when he was discovered to be an amputee, the employer decided to withdraw the offer. The rest of the amputees stated that as they are disabled nobody will employ them.

Common psychosocial problems experienced were depression, loss of dignity, phantom limbs and phantom pain, loneliness, rejection. transportation problems and poverty but the most important problem that they experienced was unemployment. Fifty percent of the men said they were lonely and spent all their time at home with very little work to do.

\section{CONCL.USION AND RECOMMENDATIONS}

Most of the amputees were found to be young men who were still single and mostly came from rural areas. Amputees who had been injured at a younger age were more ambulant and independent in activities of daily living.

Psychosocial preparation of the patients for amputation was inadequate even when days elapsed before the actual surgery was done. Information about care of the stump was given but not all the patients received this information. Poverty was an important cause of failure to purchase a prosthesis; eight men had no money to buy it and 5 were still in the process of buying it. Most of the amputees were found to be experiencing lots of problems which were physical, psycho-social and vocational in origin. Seven men had sores on their stumps, 21 men had experienced infection of the stump; 22 men complained of severe pain (including phantom pain) in the stump.

The following recommendations are made:

1. Special protocols should be formulated by the rehabilitation team for adequate preparation of patients and their relatives for amputation.

2 .Inservice and continuing education should be offered to all the nurses working with amputees, so that they give suitable health education about stump care and other aspects of rehabilitation.

3. A multidisciplinary team approach is needed in the rehabilitation of amputees to cater for physical, psycho-social and vocational needs of the amputees and to ensure proper rehabilitation.

4. The community and employers should be educated to accept the amputees in order to improve reintegration into society.

5. Further research is recommended on the high rate of stump infection to find out the cause of this.

Full rehabilitation of this young group of patients is essential, for the sakes of the individuals, families and the community.

\section{REFERENCES}

Broadhurst. C. (1989). Adjusting to amputation. Nursing Times. 5(13), 55-57.

Chilvers, A.S., \& Browse, M.L. (1971). Hospital practice. The social fate of the amputee. Lancet. 2(470), 48-50.

Dittmer, S. (1989) Rehabilitation nursing process and application. St. Louis: $\mathrm{CV}$ Mosby

Du Toit, M. (1989). The self help factory. An indigenous response to the unique circumstances of black disabled people in South Africa. Rechabilitation in South Africa 33(3). 86-90.

Farrell, J. (1982). Illuslrated guide to erthopaedic nursing. Philadelphia: J.B. Lippincots.

Footner, A. (1987). Orthopaedic Nursing. London: Bailliere Tindall 
Gillies, J. (1991). Employment of disabled people at SABAX. Rehabilitation in South Africa, 35(1), 12-17.

Martin, M., Holt, N.B., \& Hicks, D. (1981) Comprehensive Rehabilitation Nursing New York: McGraw Hill Company.

Mets, J.T., \& Wilson, C.R. (1989). Rehabilitation for employment. The Rehabilitation Centre for the association for physically disabled at Bridgetown Atholone, C.P. Rehabilitation in South Africa, 53(1), 64-68.

Park, C. (1991). A structured group programme for disfigured patients. Rehabilitation in South Africa, 35(2), 40.
Powell, M. (1982). Orthopaedic Nursing and Rehabilitation. (8th ed.). London: Churchill Livingstone.

Smith, C. (1987). Orthopaedic Nursing London: Heinemann.

Stryker, R. (1977). Rehabilitation aspects of acute and chronic nursing care (2nd ed.). Philadelphia: W.B. Saunders Company.

Thompson, D.M., \& Haran, D. (1985). Living with an amputation: The helper. Social Science Medicine, 20(4), 319-323.

Weaver, P.C., \& Marshall, S.A. (1973). A functional and social review of lower limb amputees. British J of Surgery, 60(9), 732-737.
Wilson, H. (1983). Physiotherapy for the lower limb amputee. Symposium University of Natal Medical School. 36-40.

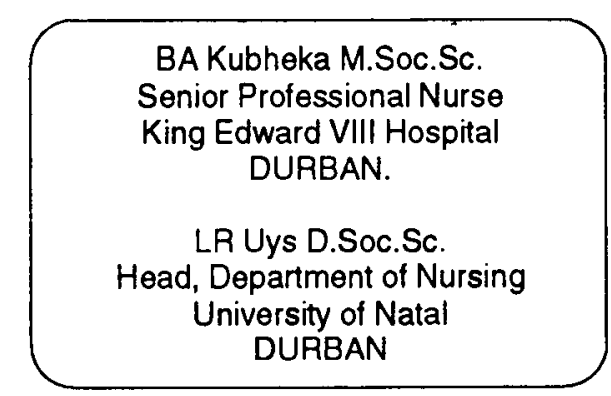

